\title{
PENGUATAN PENDIDIKAN KARAKTER MELALUI EKSTRAKURIKULER KEISLAMAN
}

\author{
Partono dan Ashif Az Zafi \\ IAIN Kudus \\ partono@iainkudus.ac.id
}

\begin{abstract}
This study aims to describe and analyze the application of extracurricular propaganda in the strengthening of character in MA NU Mu'alimat Kudus. The problem raised in this study is about the decline in morale of adolescents in Indonesia due to education in Indonesia which emphasizes more on the cognitive aspects than the affective and psychomotor aspects. Where education should be, it can make adolescents as people who have good behavior in accordance with the general objectives of education in Indonesia. In addition, character education is less optimal in its application. Therefore, character education is applied in extracurricular activities. In this study using a qualitative descriptive method. The results of this study are (1) the application of true character education already exists in extracurricular activities, this can be seen by students' observance in worship and morals displayed by students, (2) In addition to strengthening religious character, missionary extracurricular activities also internalize selfconfidence, cooperation and Responsibility.
\end{abstract}

Keywords: character education, Islamic extracurricular, da'wah, madrasa

\section{Abstrak}

Penelitian ini bertujuan untuk mendeskripsikan dan menganalisis penerapan ekstrakurikuler dakwah dalam penguatan karakter di MA NU Mu'alimat Kudus. Masalah yang diangkat dalam penelitian ini adalah mengenai turunnya moral remaja yang ada di Indonesia dikarenakan pendidikan yang ada di Indonesia lebih menekankan pada aspek kognitif saja dibandingkan dengan aspek afektif dan psikomotorik. Dimana seharusnya pendidikan yang ada, dapat menjadikan remaja sebagai insan yang kamil yang berakhlakul karimah sesuai dengan tujuan umum pendidikan yang ada di Indonesia. Selain itu, pendidikan karakter dalam penerapannya kurang maksimal. Oleh karena itu diterapkan pendidikan karakter dalam kegiatan ektrakurikuler. Dalam penelitian ini 
menggunakan metode deskriptif kualitatif. Hasil dari penelitian ini adalah (1) penerapan pendidikan karakter sejatinya sudah ada dalam kegiatan ekstrakurikuler, hal ini dapat dilihat dengan ketaatan siswa dalam beribadah dan moral yang ditampilkan siswa, (2) Selain penguatan karakter religius, ekstrakurikuler dakwah juga menginternalisasikan karakter percaya diri, kerjasama dan tanggung jawab.

Kata kunci: pendidikan karakter, ekstrakurikuler keislaman, dakwah, madrasah

\section{A. Pendahuluan}

Pendidikan sebagaimana tercantum dalam UUSPN NO. 20 tahun 2003 adalah bahwa "pendidikan bertujuan untuk mencapai berkembangnya potensi peserta didik agar menjadi manusia yang beriman dan bertakwa kepada Tuhan Yang Maha Esa, berakhlak mulia, sehat, berilmu, cakap, kreatif, mandiri, dan menjadi warga negara yang demokratis dan bertanggung jawab". Dengan kata lain melalui pendidikan akan diharapkan tercipta peserta didik yang berkembang potensinya secara maksimal baik potensi intelektual (kognitif), afektif (etika, moral, spiritual, sikap, dan pribadi), serta psikomotornya (keterampilan) sehingga semua potensi tersebut akan mendorong siswa menjadi manusia yang beriman, bertaqwa, berakhlak mulia, berilmu, cakap, kreatif, mandiri dan bertanggung jawab. Tetapi pada kenyataannya, pendidikan yang ada di Indonesia belum sepenuhnya berjalan dengan lancar sesuai yang tertera dalam UUSPN NO. 20 tahun 2003. Pada umumnya tujuan utama dari pendidikan adalah memperbaiki moral atau tingkah laku peserta didik, agar tercipta peserta didik yang berakhlakul karimah. Oleh karena itu, dari tahun ke tahun pemerintah selalu mengembangkan kurikulum yang ada di Indonesia. Walaupun begitu pendidikan yang ada di Indonesia, sebagian besar masih hanya menekankan pada aspek kognitif saja, hingga pada akhirnya terjadi perubahan kurikulum lagi yaitu Kurikulum Tingkat Satuan Pendidikan (KTSP) yang mana dalam kurikulum tersebut bukan hanya menekankan pada aspek kognitif saja tetapi juga pada aspek afektif (sikap) dan aspek psikomotorik (keterampilan). Meskipun pemerintah sudah mengembangkan kurikulum yang mana dalam kurikulum tersebut juga menekankan pada aspek afektif yaitu sikap.

Kenakalan remaja, khususnya peserta didik semakin hari semakin memprihatinkan. 
Terjadi degradasi moral di kalangan peserta didik seperti: mencuri, minum-minuman keras, berjudi, mengkonsumsi narkoba, tawuran antar pelajar, bahkan seks bebas sudah marak dilakukan oleh para peserta didik. Bahkan kegiatan tersebut seakan sudah tidak asing lagi dikalangan para pelajar dan dari tahun ke tahun selalu mengalami kenaikan sampai menelan korban jiwa. Bukan hanya itu saja, sopan dan santun yang seharusnya dimiliki oleh peserta didik, akhir-akhir ini banyak menjadi perbincangan khalayak ramai. Sebagaimana kasus guru yang dibully oleh muridnya sendiri yang terjadi di Kendal pada bulan 11 November 2018 dan juga penganiayaan guru yang dilakukan oleh muridnya yang terjadi di Gresik.

Faktor penyebab kerusakan moral yaitu kurang maksimalnya transfer of value (pendidikan karakter) di sekolah. Menghadapi fenomena kenakalan remaja tersebut, institusi pendidikan biasanya dipandang sebagai satu alternatif jalan keluar yang cukup mampu mengatasi kemerosotan moral dan perilaku tidak terpuji di kalangan anak dan remaja. Institusi ini memang berfungsi sebagai tempat pembelajaran berbagai ilmu pengetahuan sekaligus pembentuk karak- ter peserta didik. Dalam beberapa tahun belakangan, fungsi institusi pendidikan sebagai pembentuk karakter peserta didik dinilai menurun, karena lebih menitikberatkan fungsinya pada pembelajaran ilmu pengetahuan.

Misalnya memandang bahwa dua faktor dari enam faktor yang menjadi titik lemah sistem pendidikan, yaitu: pertama, pendidikan yang ada tidak berorientasi pada pembentukan kepribadian, melainkan lebih berorientasi pada sisi kognitif peserta didik. Kedua, anak tidak pernah dibiasakan untuk kreatif dan inovatif serta berorientasi pada keinginan untuk tahu.

Pada tahun ajaran 2012/2013 Kementerian Pendidikan dan Kebudayaan mencanangkan gerakan nasional pendidikan karakter mulai tingkatan sekolah dasar sampai pada tingkatan perguruan tinggi sebagai solusi dari masalah degradasi moral yang ada di kalangan peserta didik. Pendidikan karakter selain menjadi bagian dari proses pembentukan akhlak anak bangsa juga diharapkan mampu menjadi pondasi utama dalam meningkatkan derajat dan martabat bangsa Indonesia. Di lingkungan Kementerian Pendidikan Nasional sendiri, pendidikan karakter menjadi fokus pendidikan di seluruh 
jenjang pendidikan yang dibinanya. Alasan perlunya membangun karakter bangsa yakni keberadaan karakter dalam bangsa merupakan pondasi. Bangsa yang memiliki karakter kuat, mampu menjadikan dirinya sebagai bangsa yang bermartabat dan disegani oleh bangsa-bangsa lain. Dengan diterapkannya pendidikan karakter ini, pemerintah berharap dapat mewujudkan tujuan utama dari pendidikan yaitu menciptakan peserta didik yang beriman, bertakwa kepada Allah serta berakhlakul karimah. Namun, pencanangan tersebut dianggap kurang berhasil dalam memperbaiki moral peserta didik untuk menjadi insan yang kamil. Hal tersebut dikarenakan, sekolah-sekolah yang ada di Indonesia hanya mampu mengahasilkan lulusan-lulusan yang intelegen tanpa diimbangi moral yang tinggi juga.

Banyak lulusan-lulusan di luar sana mempunyai nilai yang tinggi, dapat predikat lulusan terbaik, dapat mengerjakan soalsoal dengan cepat tetapi pada kenyataannya moral mereka kurang. Banyak para pejabat lulusan dari universitas ternama yang melakukan korupsi, bahkan hal tersebut sudah marak di Indonesia. Hal tersebut dikarenakan kurangnya pengembangan dalam penerapan pendidikan karakter yang ada di Indonesia, sehingga peserta didik kebanyakan lebih mementingkan intelektualnya saja tanpa diimbangi penanaman moral dalam diri peserta didik.

Para ahli berpandangan bahwa secara mikro pengembangan karakter dibagi dalam empat pilar, yakni kegiatan pembelajaran di kelas, kegiatan keseharian dalam bentuk pengembangan budaya satuan pendidikan formal dan nonformal, kegiatan kokurikuler dan ekstrakurikuler, serta kegiatan keseharian di rumah dan masyarakat (Direktorat Ketenagaan Dirjen Dikti, 2010).

Dalam mengatasi permasalahan tersebut, sekolah-sekolah mulai mengembangkan pendidikan karakter melalui kegiatan ekstrakurikuler, yang mana melalui kegiatan ekstrakurikuler tersebut, peserta didik diharapkan mampu menerapkan pendididikan karakter secara maksimal. Kegiatan ekstrakurikuler yang selama ini diselenggarakan sekolah dianggap sebagai salah satu media yang potensial untuk pembinaan karakter dan peningkatan mutu akademik peserta didik.

Salah satu pengembangan pendidikan karakter yaitu melalui ekstrakurikuler dakwah yang 
berada di MA NU Mu'alimat Kudus. Dakwah sendiri merupakan anjuran yang harus dilakukan oleh setiap manusia untuk mensyiarkan agama Islam. Dengan ektsrakurikuler dakwah juga diharapkan penerapan pendidikan karakter dapat meningkatkan nilai-nilai keagamaan yang ada dalam diri peserta didik. Rumusan masalah yang akan dibahas yaitu Bagaimana ekstrakurikuler dakwah dalam menginternalisasikan karakter religius dan bagaimana ekstrakurikuler dakwah menguatkan karakter siswa.

Penelitian ini merupakan penelitian lapangan (field research) yang diadakan di MA NU Mu'alimat Kudus, dengan alasan kebanyakan madrasah di Kudus tidak terdapat ekstrakurikuler dakwah dan hanya beberapa madrasah saja yang menerapkan ekstrakurikuler dakwah tersebut, selain itu madrasah tersebut mewajibkan peserta didiknya untuk mengikuti ekstrakurikuler dakwah. Dalam penelitian ini yang menjadi fokus penelitian adalah penerapan pendidikan karakter dalam meningkatkan nilainilai keagamaan melalui program ekstrakurikuler dakwah. Analisis data yang digunakan adalah analisis kualitatif. Adapun analisis yang digunakan pada penelitian ini adalah metode deskriptif kualitatif, yaitu setelah semua data yang diperlukan telah terkumpul kemudian disusun dan diklasifikasikan, selanjutnya dianalisis kemudian diintrepetasikan dengan kata-kata sedemikian rupa untuk menggambarkan objek-objek penelitian dilakukan, sehingga dapat diambil kesimpulan secara proposional dan logis (Sugiyono, 2009).

\section{B. Pembahasan}

\section{Pendidikan Karakter dalam Ekstrakurikuler}

Allport sebagaimana dikutip Suryabrata (1998: 2) mengatakan "character" is personality evaluated, and personality is character devaluated, yang artinya watak atau karakter adalah kepribadian yang dinilai atau berkenaan dengan normanorma. Menurut Saptono, secara konseptual, istilah karakter dipahami dalam dua pengertian yang saling bertolak belakang. Pertama, pengertian yang bersifat deterministik. Dalam pengertian ini karakter dipahami sebagai sekumpulan kondisi rohaniah pada diri seseorang yang ada secara kodrati, given. Oleh karenanya, kondisi tersebut harus diterima dan tidak bisa diubah, bersifat tetap, menjadi tanda khusus yang membedakan orang yang satu dengan lainnya. Kedua, 
pengertian yang bersifat nondeterministik. Dalam pengertian ini, karakter dipahami sebagai tingkat kekuatan atau ketangguhan seseorang dalam upaya mengatasi kondisi rohaniah yang sudah given dan merupakan proses yang dikehendaki oleh seseorang untuk menyempurnakan kemanusiaannya.

Dari dua pengertian tersebut, akhirnya muncul pengertian ketiga yang memandang bahwa karakter merupakan kondisi rohaniah yang belum selesai, bisa diubah, dikembangkan, dan bahkan bisa diterlantarkan sehingga mutunya tidak meningkat dan terpuruk. Berdasarkan pemahaman ini, maka orang yang pasrah pada kondisikondisi diri yang sudah ada, disebut berkarakter lemah (Saptono, 2011). Karakter sendiri dapat dipilah menjadi dua, karakter lemah dan karakter baik. Karakter lemah dari warga bangsa kita menurut Koentjaraningrat dan Muchtar Lubis adalah meremehkan mutu, suka menerabas, tidak percaya diri sendiri, tidak berdisiplin, mengabaikan tanggung jawab, hipokrit, lemah kreativitas, etos kerja buruk, suka feodalisme, dan tak punya malu.

Sementara Dennis Coon dalam bukunya Introduction to Psychology: Exploration and
Aplication mendefinisikan karakter sebagai suatu penilaian subyektif terhadap kepribadian seseorang yang berkaitan dengan atribut kepribadian yang dapat atau tidak dapat diterima oleh masyarakat. Karakter adalah jawaban mutlak untuk menciptakan kehidupan yang lebih baik didalam masyarakat. Secara bahasa karakter dapat pula dipahami sebagai sifat dasar, kepribadian, perilaku/tingkah laku, dan kebiasaan yang berpola. Perspektif pendidikan karakter adalah peranan pendidikan dalam membangun karakter peserta didik. (Al-Rasyid, 2014)

Kretschmer menjelaskan karakter adalah keseluruhan totalitas kemungkinan kemungkinan bereaksi secara emosional dan volisional seseorang, yang terbentuk selama hidupnya oleh unsur-unsur dari dalam (dasar, keturunan, faktor-faktor endogen) dan unsur-unsur dari luar (pendidikan, dan pengalaman, faktor eksogen) (Suryabrata, 1998). Dari dua pendapat di atas dapat disimpulkan bahwa karakter adalah menunjuk pada kepribadian yang dinilai berdasarkan nilai norma-norma yang baik sebagai reaksi secara emosional dan volisional seseorang yang terbentuk selama hidupnya oleh 
unsur dari dalam dan unsur dari luar.

Karakter juga dapat dimaknai sebagai cara berfikir dan berperilaku yang khas tiap individu, baik dalam lingkup keluarga, masyarakat, bangsa, dan negara. Individu yang berkarakter baik adalah individu yang dapat membuat keputusan dan siap mempertanggung jawabkan setiap akibat dari keputusannya. Karakter dapat dianggap sebagai nilai-nilai perilaku manusia yang berhubungan dengan Tuhan Yang Maha Esa, diri sendiri, sesama manusia, lingkungan, dan kebangsaan yang terwujud dalam pikiran, sikap, perasaan, perkataan, dan perbuatan berdasarkan normanorma agama, hukum, tata karma, budaya, adat itiadat, dan estetika (Samani \& Hariyanto, 2013). Karakter tersusun dari tiga bagian yang saling berhubungan, yakni: moral knowing (pengetahuan moral), moral feeling (perasaan moral), dan moral behavior (perilaku moral). Karakter yang baik terdiri dari pengetahuan tentang kebaikan (knowing the good), keinginan terhadap kebaikan (desiring the good), dan berbuat kebaikan (doing the good). Dalam hal ini, diperlukan pembiasaan dalam pemikiran (habits of the mind), dan pembiasaan dalam tindakan (habits of the heart), dan pembiasaan dalam tindakan (habit of the action)

Pendidikan karakter adalah upaya yang dilakukan dengan sengaja untuk mengembangkan karakter yang baik (good character) berlandaskan kebajikan-kebajikan inti (core virtues), yang secara objektif baik bagi individu maupun masyarakat (Saptono, Dimensi-dimensi Pendidikan Karakter, 2011). Pendidikan karakter juga dapat didefinisikan sebagai pendidikan yang mengembangkan karakter mulia dari peserta didik yang telah memiliki pengetahuan, merasakan pengetahuan itu, dan mempraktikkan nilai-nilai moral itu. Pendidikan karakter juga membantu peserta didik untuk mengambil keputusan yang beradab dalam hubungannya dengan sesama manusia maupun dalam hubungannya dengan Tuhannya (Q-Anees \& Hambali, 2008). Muhlas Samani mendefinisikan pendidikan karakter sebagai upaya yang sungguh-sungguh untuk membantu seseorang memahami, peduli, dan bertindak dengan landasan inti nilai-nilai etis. (Samani, Konsep dan Model Pendidikan Karakter, 2011)

Pendidikan Karakter juga dapat didefinisikan sebagai upaya 
penyiapan kekayaan batin peserta didik yang berdimensi agama, sosial, budaya, yang mampu diwujudkan dalam bentuk budi pekerti, baik dalam perbuatan, perkataan, pikiran, sikap, perasaan, dan kepribadian. Pendidikan karakter dimaknai dengan suatu sistem penanaman nilainilai karakter kepada warga sekolah yang meliputi komponen pengetahuan, kesadaran, atau kemauan, dan tindakan untuk melaksanakan nilai-nilai tersebut baik terhadap Tuhan Yang Maha Esa, diri sendiri, sesama, lingkungan, maupun kebangsaan sehingga menjadi manusia insan kamil (Samani \& Hariyanto, Konsep dan Model Pendidikan Karakter, 2011). Sedangkan Wibowo (2012: 36) mendefinisikan pendidikan karakter dengan pendidikan yang menanamkan dan mengembangkan karakterkarakter luhur kepada anak didik, sehingga mereka memiliki karakter luhur itu, menerapkan dan mempraktikkan dalam kehidupannya baik di keluarga, masyarakat, dan negara.

Pendapat lain yang dikemukakan Lickona (Q-Anees \& Hambali, 2008) menyimpulkan bahwa pendidikan karakter adalah upaya dengan sengaja menolong orang agar memahami, peduli akan dan bertindak atas dasar inti nilai-nilai etis. Seseorang dapat dikatakan berkarakter bila seseorang tersebut perilakunya sesuai dengan kaidah moral. Pendidikan karakter adalah suatu sistem penanaman nilai-nilai karakter yang baik kepada semua yang terlibat dan sebagai warga sekolah sehingga mempunyai pengetahuan, kesadaran, dan tindakan dalam melaksanakan nilai-nilai tersebut. Dari pengertian diatas dapat disimpulkan bahwa pendidikan karakter yaitu proses pendidikan yang sengaja dirancang untuk menanamkan nilai-nilai karakter peserta didik sehingga mereka mampu menerapkan dalam kehidupannya baik di keluarga, sekolah, masyarakat, negara dan dapat memberikan kontribusi yang positif kepada lingkungannya.

Secara sederhana ekstrakurikuler mengandung pengertian yang menunjukkan segala macam aktivitas di sekolah atau lembaga pendidikan yang dilaksanakan di luar jam pelajaran. Tujuan dari kegiatan ini adalah memperluas pengetahuan, memahami antara keterkaitan berbagai materi pelajaran, penyaluran antara bakat, minat serta dalam rangka untuk meningkatkan kualitas keimanan dan ketakwaan para siswa terhadap Tuhan Yang Maha 
Esa (YME), kesadaran berbangsa dan bernegara, berbudi pekerti luhur dan lain sebagainya. Berdasarkan uraian di atas dapat disimpulkan bahwa kegiatan ekstrakurikuler adalah kegiatan tambahan yang di luar struktur program, dilaksanakan di luar jam pelajaran biasa agar memperkaya dan memperluas wawasan pengetahuan dan kemampuan siswa.

Sebagai bagian dari pendidikan maka kebijakan mengenai kegiatan ekstra-kurikuler merupakan bagian dari kebijakan Departemen Pendidikan Nasional yang sebelum era reformasi disebut Departemen Pendidikan dan Kebudayaan. Kegiatan ekstrakurikuler pada masa itu dilakukan dengan berlandaskan pada surat Keputusan (SK) Menteri Pendidikan dan kebudayaan (Mendikbud) Nomor 0461/ U/1964 dan Surat Keputusan (SK) Direktur Jenderal Pendidikan Dasar dan Menengah (Dirjen Dikdasmen) Nomor: 226/C/Kep/ O/1992, dinyatakan bahwa ekstrakurikuler merupakan salah satu jalur pembinaan kesiswaan disamping jalur Organisasi Siswa Intra Sekolah (OSIS), latihan kepemimpinan dan wawasan wiyatamandala. Berdasarkan kedua Surat Keputusan tersebut ditegaskan pula bahwa ekstrakurikuler sebagai bagian dari kebijaksanaan pendidikan secara menyeluruh yang mempunyai tugas pokok yaitu memperdalam dan memperluas pengetahuan peserta didik, mengenal hubungan antara berbagai mata pelajaran, menyalurkan bakat dan minat, melengkapi upaya pembinaan manusia seutuhnya.

Kegiatan ekstrakurikuler yang selama ini diselenggarakan sekolah dianggap sebagai salah satu media yang potensial untuk pembinaan karakter dan peningkatan mutu akademik peserta didik. Melalui kegiatan ekstrakurikuler diharapkan dapat mengembangkan kemampuan dan tanggung jawab sosial, potensi dan prestasi peserta didik. Kegiatan ekstrakurikuler adalah kegiatan pendidikan di luar mata pelajaran dan pelayanan konseling untuk membantu pengembangan peserta didik sesuai kebutuhan, potensi, bakat, dan minat mereka. Implementasi pendidikan karakter dalam kegiatan ekstrakurikuler merupakan langkah yang strategis.

Kegiatan ekstrakurikuler bisa berupa olahraga, sastra, budaya, kepemimpinan, kewirausahaan, kesehatan, dan keagamaan. Kegiatan ekstrakurikuler merupakan seperangkat pengalaman belajar, tentunya memiliki nilai manfaat bagi pembentukan 
kepribadian siswa. Salah satunya kegiatan ekstrakurikuler adalah ekstrakurikuler dakwah. Ekstrakurikuler dakwah merupakan suatu kegiatan siswa yang dilaksanakan di luar jam proses belajar mengajar yang membahas tentang ketaatan beragama siswa, mengajak siswa untuk amr ma'ruf nahy munkar, selain itu untuk pendalaman siswa agar dapat berdakwah dengan baik.

\section{Penerapan Ekstrakurikuler Dakwah}

Kegiatan ekstrakurikuler penting untuk mengasah minat, bakat dan potensi siswa. Menurut Arikunto kegiatan ekstrakurikuler adalah kegiatan tambahan, di luar struktur program yang pada umumnya merupakan kegiatan pilihan (Suryosubroto, 2009). Pelaksanaan kegiatan ekstrakurikuler di MA NU Mu'allimat Kudus dilaksanakan di luar proses belajar mengajar. Berbagai ekstrakurikuler yang dilaksanakan di MA NU Mu'alimat Kudus, antara lain; Pamuka, PMR, dakwah, bidang olahraga, bidang seni budaya, dan yang lainnya. Salah satu keunikan dan yang jarang dimiliki oleh sekolah lain adalah kegiatan ekstrakurikuler dakwah.

Pelaksanaan kegiatan ekstrakurikuler dakwah di MA NU
Mu'allimat Kudus dilaksanakan di luar jam pelajaran dan kegiatan ekstrakurikuler ini wajib diikuti kelas $X$ dan kelas XI. Kegiatan ekstrakurikuler dakwah dilaksanakan satu minggu sekali, yaitu pada setiap hari senin, pukul 14.00-16.00. Ekstrakurikuler dakwah dilaksanakan dengan susunan acara sebagai berikut: Pertama, untuk meramaikan dan menarik minat siswi agar mengikuti kegiatan ekstrakurikuler dakwah, maka melantunkan sholawat yang diiringi oleh grup rebana. Kedua, pembukaan merupakan tanda acara dimulai. Ketiga, pembacaan ayat suci AlQur'an dan shalawat Asnawiyah. Keempat, latihan khitobah atau pidato, yang dilaksanakan oleh salah satu siswi yang mendapat tugas. Kelima merupakan acara inti yaitu al-mau'izah al-hasanah. Petugas pelaksanaan ekstrakurikuler dakwah merupakan sisiwi kelas $X$ dan XI, akan tetapi sistemnya bergiliran setiap kali pertemuan. Seperti, minggu pertama yang bertugas dari kelas $X$, minggu kedua dari I IPA 1 , dan seterusnya.

Pada dasarnya tujuan adalah sesuatu yang hendak dicapai melalui tindakan, perbuatan serta usaha. Dalam kaitannya dengan pelaksanaan kegiatan ekstrakurikuler dakwah di MA NU 
Mu'allimat Kudus, maka tujuannya adalah (1) Untuk menambah ilmu tentang ajaran agama Islam; (2) Meningkatkan mutu pendidikan sekolah dalam bidang agama Islam; (3) Untuk mencetak generasi muda yang berjiwa akhlaq al-kari-mah; (4) Untuk menambah ilmu agama serta mendalami tentang ajaran agama Islam. Selain itu, melatih diri untuk berani tampil percaya diri ketika berpidato; (5) Untuk menambah bekal ilmu pengetahuan agama Islam, serta menambah percaya diri untuk tampil di depan dalam berpidato, karena kelak akan terjun ke lingkup masyarakat.

$$
\text { Unsur-unsur }
$$

dalam

pelaksanaan kegiatan ekstrakurikuler dakwah di MA NU Mu'allimat Kudus adalah (1) Pelaku dakwah dalam kegiatan ekstrakurikuler dakwah di MA NU Mu'allimat Kudus adalah guru pembimbing ekstrakurikuler yang berperan sebagai Da'i. Pelaku dakwah pada pelaksanaan kegiatan ekstrakurikuler dakwah di MA NU Mu'allimat terdiri dari guru pembimbing ekstrakurikuler dakwah dan siswi yang bertugas untuk menyampaikan materi setiap kali pertemuan; (2) Adapun peran siswi kelas $X$ dan kelas $X I$ MA NU Mu'allimat Kudus sebagai penerima materi dakwah, atau Mad'u; (3) Maddah (materi dakwah), materi yang disampaikan sesuai ajaran agama Islam, dan penyampaian setiap kali pertemuan tentunya beda tema, antara lain yang membahas bagian dari ajaran agama Islam, yaitu; materi tentang akidah, syari'ah, dan akhlak; (4) Wasilah (media dakwah), media yang digunakan dalam ekstrakurikuler dakwah, yaitu dengan media lisan dan suara. Diantaranya menggunakan pengeras suara (sound dan microphone), ruang kelas, meja, dan kursi untuk untuk duduk $D a ' i$ dan Mad'u; (5) Metode (Thariqah) yang digunakan dalam pelaksanaan kegiatan ekstrakurikuler dakwah di MA NU Mu'allimat Kudus menggunakan metode hikmah dan mau'izah al-hasanah; (6) Atsar (efek dakwah), maka efek siswi setelah mengikuti ekstrakurikuler dakwah dapat mempraktekkan materi yang telah didapatkan, maksudnya dapat mempraktekkan materi yang telah didapatkan dalam isi khitobah yang disampaikan da'i (guru pembimbing dan siswi yang bertugas). Mempunyai akhlak dan budi pekerti yang baik dalam kehidupan sehari-hari, menanamkan sikap sopan-santun terhadap orangtua, guru, serta masyarakat pada umumnya. Selain itu, siswa sudah mempunyai bekal serta 
persiapan yang matang dalam melaksanakan tugas praktek mengajar yang dilaksanakan siswi saat kelas XII.

Metode yang digunakan untuk menyampaikan materi dakwah dalam pelaksanaan kegiatan ekstrakurikuler dakwah menggunakan metode bi al-lisan yaitu hikmah dan mau'izah al-hasanah. Dengan demikian, para siswi

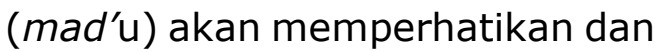
menyerap tentang materi yang disampaikan da'i. Penggunaan metode bi al-lisan yaitu hikmah dan mau'izah al-hasanah, diharapkan para siswi (mad'u) untuk dapat mengikuti dan memperhatikan penyampaian materi yang disampaikan oleh da'i dalam pelaksanaan kegiatan ekstrakurikuler dakwah. Materi yang disampaikan oleh da'i kepada mad'u dalam pertemuan pelaksanaan ekstrakurikuler dakwah berbeda tema, setiap contoh keutamaan puasa rajab, keutamaan shalat sunah dhuha, maulid Nabi Muhammad SAW dan yang lainnya. Adapun materi yang disampaikan oleh da'i dalam khitobah tiap kali pertemuan pembahasan temanya berbeda, seperti; Isra' Mi'raj, Maulid Nabi Muhammad SAW, keutamaan di bulan Sya'ban, tentang shalat wajib (shalat lima waktu) maupun sunnah (keutamaan shalat sunnah dhuha), bergaul sesama teman, tata cara bertingkah laku yang baik, cara berpenampilan Muslimah, menerapkan sikap sopan santun kepada orang tua dan guru.

\section{Penguatan Nilai-nilai Religius}

Berdasarkan pengertian ten-tang pendidikan karakter yang sudah diuraikan di depan, bahwa pendidikan karakter adalah upaya dengan sengaja menolong siswa agar memahami, peduli dan bertindak atas dasar inti nilai-nilai etis. Seseorang dapat dikatakan berkarakter bila seseorang tersebut perilakunya sesuai dengan kaidah moral. Jadi inti dari pendidikan karakter adalah moralitas sebagai bangunan karakter yang harus dimiliki siswa sebagai modal dalam bersikap dan berperilaku dalam hidup dan kehidupannya, baik dalam hidup sehari-hari berkaitan dengan dirinya maupun hidup bermasyarakat. Dalam konteks pendidikan karakter, yang menjadi unsur utama adalah peserta didik atau siswa sedang siswa secara naluriah dan alamiah dalam pandangan Islam sudah memiliki potensi "fitrah" atau dasar pembawaan yang baik namun sifat pembawaan dasar tadi tidak secara otomatis menjadi baik tanpa 
pendidikan. Dengan demikian semua fitrah peserta didik tadi juga harus dikawal dengan pendidikan agar menjadi baik.

Dalam kegiatan ekstrakurikuler dakwah di MA NU Mu'alimat Kudus dapat diketahui bahwa kegiatan ekstrakurikuler adalah kegiatan yang dilakukan diluar jam pelajaran sekolah. Seperti definisi aslinya bahwa kegiatan ekstrakurikuler yaitu kegiatan yang dilaksanakan diluar jam pelajaran sekolah. Tujuan dari kegiatan ini adalah memperluas pengetahuan, terutama dalam bidang keagamaan, memahami antara keterkaitan berbagai materi pelajaran dengan tema dakwah yang disampaikan oleh siswa dalam kegiatan ekstrakurikuler dakwah, penyaluran antara bakat, minat serta dalam rangka untuk meningkatkan kualitas keimanan dan ketakwaan para siswa terhadap Tuhan Yang Maha Esa (YME), berbudi pekerti luhur dan lain sebagainya (Zafi, 2019).

Penerapan pendidikan karakter dalam meningkatkan nilainilai keagamaan melalui ekstrakurikuler dakwah di MA NU Mu'alimat Kudus setelah penulis melakukan observasi dan wawancara, sebenarnya sudah terkandung di dalam kegiatan ekstrakurikuler dakwah, hal tersebut dapat dilihat dengan bertambahnya ketaatan siswa dalam beragama dan siswa menjadi lebih patuh terhadap ajaran agama Islam. Awalnya sebelum para siswa mengikuti ekstrkurikuler dakwah dalam hal akhlak, terkadang terdapat siswa yang pernah juga melakukan akhlak tercela seperti kurangnya sopan santun kepada orang yang lebih tua, cuek (kurang perhatian) ketika teman ada musibah. Adapun dari segi penerapan ibadah masih belum sempurna, kurang khusyuk dalam melaksanakan shalat. Selain itu, pelaksanaan ibadah mahdhah para siswi sebelum mengikuti ekstrakurikuler dakwah, hanya menjalankan ibadah wajib saja.

Tetapi setelah para siswa mengikuti kegiatan ekstrakurikuler dakwah para siswa mendapatkan materi tentang agama. Para siswa menjadi semakin rajin dalam beribadah dan mengerjakan ibadah ghairu mahdhah. Dari segi akhlak sudah terbiasa untuk mempraktikan akhlak yang baik seperti menerapkan sikap sopan santun kepada orang tua dan guru, tata cara bertingkah laku yang baik, peduli terhadap teman dan cara berpenampilan Muslimah. Dari tingkat ibadah, setelah mengikuti kegiatan ekstrakurikuler dakwah, maka siswa tergugah untuk lebih giat beribadah. 
Seperti mulai melakukan shalat sunnah dhuha ketikajam istirahat tiba, selain itu melaksanakan puasa sunnah rajab, puasa sunnah hari senin dan hari kamis.

Bukan hanya itu saja, para siswa setelah mengikuti ekstrakurikuler dakwah, sesama teman dapat berinteraksi dengan baik serta menghargai, ketika sudah mulai waktu shalat dhuhur, para siswi melaksanakan shalat dhu-

hur dengan berjamaah, karena waktu shalat dhuhur bersamaan dengan istirahat kedua, para siswi juga memanfaatkan waktu istirahat pertama dengan mengerjakan amalan sunnah, seperti shalat dhuha, perilaku siswi dalam keseharian dapat dilihat setelah mengikuti ekstrakurikuler dakwah adalah minimnya dalam melanggar peraturan tata tertib yang sudah ditetapkan di sekolah.

Dari penjelasan di atas dapat disimpulkan bahwa ekstrakurikuler dakwah menginternalisasikan nilai utama yaitu religius. Hal tersebut dapat dilihat dari akhlak pada diri siswa yang memperlihatkan akhlak terpuji terhadap sesama teman maupun kepada guru dan orang tua serta pelaksanaan ibadah seperti melakukan ibadah sunnah yaitu melakukan sholat dhuha saat jam istirahat kedua serta puasa senin kamis. Selain itu, ekstrakurikuler dakwah juga menginternalisasikan nilai disiplin, kerjasama dan tanggung jawab.

\section{Simpulan}

Penerapan pendidikan karakter bukan hanya dalam proses pembelajaran berlangsung, tetapi pendidikan karakter juga dapat diterapkan di luar jam pelajaran, yaitu pada saat kegiatan ekstrakurikuler. Sekarang ini banyak sekolah-sekolah yang menerapkan pendidikan karakter dalam kegiatan ekstakurikuler, salah satunya yaitu di MA NU Mu'alimat Kudus, yang menjadi keunikan tersendiri dari sekolah ini yaitu adanya kegiatan ekstrakurikuler dakwah yang mana kegiatan ekstrakurikuler tersebut sangat jarang ada di sekolah-sekolah atau madrsah-madrasah yang lain.

Kegiatan ekstrakurikuler dakwah yang ada di MA NU Mu'alimat Kudus, sejatinya sudah menerapkan pendidikan karakter di dalamnya. Hal ini berdasarkan dari penjelasan bahwa ekstrakurikuler dakwah menginternalisasikan nilai utama yaitu religius. Hal tersebut dapat dilihat dari akhlak pada diri siswa yang memperlihatkan akhlak terpuji terhadap sesama teman maupun kepada guru dan orang tua serta pelaksanaan ibadah seperti mela- 
Jurnal Inteligensia: STAIN Gajah Putih Aceh, Volume 8, No. 1 Maret 2020

kukan ibadah sunnah yaitu dakwah juga menginternalisasmelakukan sholat dhuha saat jam ikan nilai disiplin, kerjasama dan istirahat kedua serta puasa senin tanggung jawab.

kamis. Selain itu, ekstrakurikuler 


\section{PUSTAKA ACUAN}

Abud, Al-Ghoniy, Abudu. 1992. Aqidah Islam VS Ideologi Modern.

Ponorogo: Trimurti Press.

Alfian, Toni. tt. Petunjuk Pelaksanaan Kegiatan. Suryosubroto, B. 2009.

Proses Belajar Mengajar di Sekolah. Jakarta: Rineka Cipta.

Al-Rasyid, Moh. Harun. 2014. Implementasi Pendidikan Karakter Dalam

Mata Pelajaran Pendidikan Agama Islam (PAI) Di Sma Darussalam

Blokagung Banyuwangi. Darussalam: Jurnal Pendidikan, Komunikasi,

dan Pemikiran Hukum Islam Vol. VI No. 1.

Azizy, A. Qadri A. 2003. Pendidikan (Agama) untuk Membangun Etika

Sosial. Semarang: Aneka Ilmu.

Direktorat Ketenagaan Dirjen Dikti. 2010. Kerangka Acuan Pendidikan

Karakter, Tahun Anggaran 2010. Jakarta: Kementerian Pendidikan

Nasional.

Indrastoeti SP, Jenny. Penanaman Nilai-Nilai Karakter Melalui

Implementasipendidikan Karakter Di Sekolah Dasar. Prosiding

Seminar Nasional Inovasi Pendidikan Inovasi Pembelajaran Berbasis

Karakter dalam Menghadapi Masyarakat Ekonomi ASEAN

Ismail, Usman, Asep, dkk. 2005. Tasawuf. Jakarta: Pusat Studi Wanita.

Mubarok, Zaky, dkk. 2001. Akidah Islam. Jogjakarta: UII Press

Munir, Samsul Amin. 2009. Ilmu Dakwah. Jakarta: Amzah.

Q-Anees, Bambang dan Adang Hambali. 2008. Pendidikan Karakter

Berbasis Al-Qur'an. Bandung: Simbiosa Media.

Samani, Muchlas dan Hariyanto. 2011. Konsep dan Model Pendidikan

Karakter. Bandung: Remaja Rosda Karya.

Saptono. 2011. Dimensi-dimensi Pendidikan Karakter. Jakarta: Erlangga.

Sugiyono. 2009. Memahami Penelitian Kualitatif. Alfabeta: Bandung

Suryabrata, Sumadi. 1998. Pengembangan Alat Ukur Psikologis. Jakarta:

Dirjen Dikti Depdikbud.

Suryosubroto, B. 2009. Proses Belajar Mengajar di Sekolah. Jakarta

Rineka Cipta.

Syabibi, Ridho. 2008. Metodologi Ilmu Dakwah. Bengkulu: Pustaka

Pelajar.

UUSPN No 20 Tahun 2003, Jararta: Diknas

Zafi, Ashif Az. 2019, "Nilai Nasionalisme Kebangsaan Aktivis Rohis", Belajea: Jurnal Pendidikan Islam, Bengkulu: IAIN Curup. 